\title{
SIMULTANEOUS DETERMINATION OF SULFONYLUREA HERBICIDE SYNTHETIC BINARY MIXTURES BY A PARTIAL LEAST SQUARE METHOD COMBINED WITH MICELLAR-ENHANCED PHOTOCHEMICALLY-INDUCED FLUORESCENCE APPLICATION TO TAP WATER ANALYSIS
}

\author{
Atanasse Coly ${ }^{1}$, Jean-Jacques Aaron ${ }^{2,3}$ \\ ${ }^{1}$ Laboratoire de Photochimie et d'Analyse (LPA), Faculté des Sciences et Techniques, \\ Département de Chimie, Université Cheikh Anta DIOP, Dakar, Sénégal \\ ${ }^{2}$ Laboratoire ITODYS de l' Université Paris 7-Denis Diderot - CNRS - UMR 7086, \\ Bâtiment Lavoisier - 15 rue Jean de Baïf - 75205 Paris Cedex 13, France \\ ${ }^{3}$ Université Paris - Est Marne la Vallée, Laboratoire G2I, \\ 5 boulevard Descartes, Champs-sur-Marne, 77454 Marne-la-Vallée Cedex 2, France \\ jeanjacquesaaron@yahoo.fr
}

\begin{abstract}
A combination of the partial least square method in its first variable (PLS-1) with micellar-enhanced photochemically-induced fluorescence (MEPIF) was developed for the simultaneous determination of synthetic binary mixtures of four sulfonylurea herbicides in aqueous micellar solutions, and applied to tap water analysis. Because of their similar features, the MEPIF emission spectra of these herbicides were found to severely overlap in the whole wavelength region. After optimization of the calibration matrix, the PLS-1-MEPIF method was applied to the resolution of chlorsulfuron/metsulfuron methyl and sulfometuron methyl/3-rimsulfuron binary mixtures. The analytical results obtained by the PLS-1-MEPIF method were presented and compared to those of the first-derivative PIF one. An application of the PLS-1-MEPIF method to the quantitative analysis of Paris tap water samples spiked with the herbicide binary mixtures led to recovery values ranging between 63 and $118 \%$, depending on the mixture.
\end{abstract}

Key words: partial least square; micellar-enhanced photochemically-induced fluorescence; sulfonylurea herbicides; tap water analysis

\section{СИМУЛТАНО ОПРЕДЕЛУВАЊЕ НА БИНАРНИ СУЛФОНИЛУРЕА ХЕРБИЦИДНИ СМЕСИ СО МЕТОДОТ НА ПАРЦИЈАЛНИ НАЈМАЛИ КВАДРАТИ КОМБИНИРАН СО МИЦЕЛАРНО ЗАСИЛЕНА ФОТОХЕМИСКИ ИНДУЦИРАНА ФЛУОРЕСЦЕНЦИЈА ПРИМЕНЕТА НА ВОДА ОД ЧЕШМА}

\footnotetext{
Разработен е метод на симултано определување на бинарни смоли од четири сулфонилуреа хербициди во водни мицеларни раствори со комбинација на метод на парцијални најмали квадрати (PLS-1) со мицеларно засилена фотохемиски индуцирана флуоресценција (MEPIF). Поради сличните својства, добиените MEPIF емисиони спектри на овие хербициди во голем степен се преклопуваат во целата бинарна област. По оптимизација на калибрационата матрица методот PLS-1-MEPIF беше применет за раздвојување на претходно подготвени бинарни смеси од хлоросулфурон/метсулфурон и сулфометронметил/3-римулфурон. Добиените аналитички резултати од методот PLS-1-MEPIF се презентирани и споредени со оние добиени од деривативниот метод PIF (прв извод). При примена на методот PLS-1-MEPIF за квантитативна анализа на примероци од вода од водоводната мрежа во Парис во кои се додадени бинарни смеси, во зависност од смесата се добиаат аналитички приноси меѓу 63 и $118 \%$.
}

Клучни зборови: парцијалн најмали квадрати; мицеларно засилена фотохемиски индуцирана флуоресценција; сулфонилуреа хербициди; анализа на вода од чешма 


\section{INTRODUCTION}

Partial least square (PLS) method is a very efficient numerical tool with a high resolution power. Indeed, in the case of complex samples for which spectral overlapping is often a serious limitation, PLS analyses have been shown to be extremely useful for resolving the obtained spectra [1-13]. As a consequence, the rapid development of the PLS method during the last fifteen years and its notable application to the resolution of luminescence spectra has made it complementary to the derivative spectra technique and, in some instances, an even better, alternative method [4-12]. The most remarkable feature of PLS is that the concentration levels of any interfering substance in a mixture do not need to be precisely known in advance for the mixture resolution. Therefore, a broad range of structurally-similar compounds and/or complex environmental samples can be analyzed by PLS [8, 9, 12, 13].

Sulfonylurea herbicides constitute a very important class of pesticides which were introduced in the mid-1970s for the control of weeds in crops [14]. They are characterized by very similar chemical structure, spectroscopic and physicochemical properties $[14,15]$, which make their identification and determination by using the classical luminescence methods in mixtures of two or more herbicides very difficult. In previous studies [16, 17], we have shown that the photochemically-induced fluorescence (PIF) approach was a very sensitive method for the individual determination of sulfonylurea herbicides, but was poorly selective for screening mixtures of these compounds because of the strongly-overlapping PIF spectra. However, we have been able to increase the selectivity of this method by using the first-derivative PIF ( ${ }^{1} \mathrm{D}$-PIF) spectra [18]. Indeed, we have accomplished the simultaneous determination of three binary mixtures of sulfometuron methyl with chlorsulfuron, metsulfuron methyl and 3-rimsulfuron, respectively, in aqueous micellar solutions by using the ${ }^{1}$ D-PIF method, with the zero-crossing point procedure. Nevertheless, we have been unable to resolve other mixtures, such as chlorsulfuron metsulfuron methyl mixtures, because of the strongly-overlapping PIF emission peaks.

For this reason, we decided to improve the selectivity of the PIF method by combining it with the PLS method for the determination of binary mixtures of sulfonylurea herbicides. Therefore, the aim of this work was to investigate the ability of the PLS method in its first variable (PLS-1 method), combined with the micellar-enhanced PIF (MEPIF) analytical signal, to simultaneously determine various binary mixtures of the four sulfonylurea herbicides under study. More precisely, our goal was not to resolve all the possible, binary combinations of the four herbicides, but to develop the PLS-1-MEPIF method, to evaluate its performances, and to test its capability to resolve mixtures otherwise impossible to separate by the previously-used ${ }^{1}$ D-PIF spectral technique [18]. Under these conditions, we were able to resolve two binary mixtures of sulfonylurea herbicides by using the PLS-1-MEPIF method. We also applied the developed method to the quantitative analysis of Paris tap water samples spiked with binary mixtures of the herbicides under study. From the environmental standpoint, this also shows the potential importance of the developed PLS-1-MEPIF method for the quantitative study of waters containing herbicides at trace levels.

\section{EXPERIMENTAL}

\section{Reagents}

Chlorsulfuron $(99.2 \%, \mathrm{~m} / \mathrm{m})$, metsulfuron methyl $(97.4 \%, \mathrm{~m} / \mathrm{m}), 3$-rimsulfuron $(99.1 \%, \mathrm{~m} / \mathrm{m})$ and sulfometuron methyl $(99.2 \%, \mathrm{~m} / \mathrm{m})$ were a generous gift from E.I. DuPont de Nemours and Co, Inc. (Wilmington, DE, USA). Spectroscopic grade methanol (Merck, Darmstadt, Germany) was utilized for preparing the stock solutions of herbicides. Cetyltrimethylammonium chloride (CTAC), $25 \%$ wt. solution in water (Aldrich, Milwaukee, WI, USA) and sodium dodecyl sulfate (SDS, $99 \%, \mathrm{~m} / \mathrm{m}$ ) analytical reagent grade (Acros Organics, Geel, Belgium) were used as received. Sodium hydroxide $(97 \%, \mathrm{~m} / \mathrm{m})$ was obtained from Prolabo (Rhône Poulenc, Paris, France). 20 \% (v/v) of $\mathrm{pH} 8$ buffer solutions (Acros Organics) were used for $\mathrm{pH}$ adjustment. Alkaline solutions $(\mathrm{pH}=11.8)$ were prepared with a suitable concentration of $\mathrm{NaOH}$. Distilled water was used for preparing the micellar solutions of CTAC and SDS. For analytical applications, Paris tap water samples were freshly collected in our laboratory and stored in plastic flasks at room temperature. The samples were spiked and analyzed within three days of their collection. 


\section{Apparatus and software}

All spectral measurements were performed at room temperature with a Kontron SFM-25 (Zurich, Switzerland) spectrofluorimeter interfaced with a microcomputer. Uncorrected MEPIF spectra were recorded and memorized by using a K-wind 25 data control and acquisition program (Zurich, Switzerland). An unfiltered Osram (Eurosep, CergyPontoise, France) 200 W HBO high-pressure mercury lamp with a Spotlight power supply was used for photolysis reactions. The photochemical set-up included a Schoeffel Instruments (Cunow, Paris, France) GmbH light-box consisting of a fan, the mercury lamp and a quartz lens. A standard Hellma (Mullheim, Germany) quartz fluorescence cuvette with a $1 \mathrm{~cm}$ pathlength was placed on an optical bench, at $30 \mathrm{~cm}$ from the mercury lamp. During photolysis, the solutions were stirred magnetically in the quartz cuvette.

The Microcal Origin version 6.00, application software was used for the data statistical treatment, and the Parvus version 1.3 software, for the application of PLS-1.

\section{Preparation of solutions}

Stock solutions of herbicides $\left(10^{-3} \mathrm{~mol} / \mathrm{L}\right)$ were freshly prepared by dissolving the compound in methanol. Serial dilutions were carried out with distilled water to obtain working standard solutions. All solutions were protected against light with aluminium foil and stored in a refrigerator. Stock solutions of SDS $(0.1 \mathrm{~mol} / \mathrm{L}), \mathrm{CTAC}(0.1 \mathrm{~mol} / \mathrm{L})$ and $\mathrm{NaOH}(1 \mathrm{~mol} / \mathrm{L})$ were prepared with distilled water and used for serial dilutions. Herbicide aqueous micellar solutions were prepared by transferring $10-50 \mu \mathrm{L}$ aliquots of the methanolic working standard solutions to $5 \mathrm{~mL}$ volumetric flasks, adding the needed volume of SDS or CTAC stock solution, $25 \mu \mathrm{L} 1 \mathrm{~mol} / \mathrm{L} \mathrm{NaOH}$, or $1 \mathrm{~mL} \mathrm{pH} 8$ buffer solutions and diluting to volume with distilled water. The solutions were shaken before UV irradiation and analytical measurements. All working standard solutions and aqueous micellar solutions contained less than $1 \%(\mathrm{v} / \mathrm{v})$ methanol.

\section{Photolysis reactions, analytical measurements and PLS-1-MEPIF method application}

An aliquot of the herbicide aqueous micellar solution was placed in a quartz cuvette and irradiated for a fixed time at room temperature. Curves of MEPIF intensity $\left(I_{\mathrm{F}}\right)$ vs UV irradiation time $\left(t_{\text {irr }}\right)$ were constructed at the analytical excitation $\left(\lambda_{\mathrm{ex}}\right)$ and emission $\left(\lambda_{\mathrm{em}}\right)$ wavelengths of each individual herbicide photoproduct. Time intervals of 20-60 s were used, depending on the herbicide.

Uncorrected MEPIF emission spectra were recorded at the optimum $t_{\text {irr }}\left(t_{\text {irr }}^{\text {opt }}\right)$ values, in the range of, respectively, $340-500 \mathrm{~nm}$ for the chlorsulfuron/metsulfuron methyl mixtures, and 320 $480 \mathrm{~nm}$ for the sulfometuron methyl/3-rimsulfuron mixtures, which implies 161 experimental points per spectrum. Before PLS-1 modelling, the MEPIF emission spectra were corrected for the solvent (blank) spectral signal, and smoothed. These data were then collected in a $10 \times 161$ (lines $\times$ rows) dimensional matrix before computation.

Calibration matrices of ten chlorsulfuron/metsulfuron and sulfometuron methyl/3-rimsulfuron binary mixtures were prepared according to their various concentration ratios. All the solution concentrations, used for the calibration matrices, were measured in a random order.

\section{Tap water sample analysis}

$10 \mathrm{~mL}$ Paris tap water samples were spiked with chlorsulfuron $(36.0 \mu \mathrm{g} / \mathrm{mL})$, metsulfuron methyl $(3.84 \mu \mathrm{g} / \mathrm{mL})$, 3-rimsulfuron $(4.32 \mu \mathrm{g} / \mathrm{mL})$ and sulfometuron methyl $(36.4 \mu \mathrm{g} / \mathrm{mL})$, respectively, and the solutions were stirred in an ultrasonic bath for $10 \mathrm{~min}$ before being stored in the dark, and used as the natural water stock solutions. Synthetic binary mixtures were obtained by transferring 5$200 \mu \mathrm{L}$ aliquots of the stock solutions of both components to $5 \mathrm{~mL}$ volumetric flasks, adding the needed volume of aqueous micellar solution, 25 $\mu \mathrm{L}$ of $1 \mathrm{~mol} / \mathrm{L} \mathrm{NaOH}$ solution, or $1 \mathrm{~mL}$ of $\mathrm{pH} 8$ buffer solution, and diluting to the mark with distilled water. Before being spiked with herbicides, all tap water samples were checked for the absence of fluorescent dissolved species. The recovery efficiency values were calculated using the optimized calibration matrices by application of the PLS-1-MEPIF method. 


\section{RESULTS AND DISCUSSION}

\section{Preliminary MEPIF studies}

Initially, we investigated the PIF spectral properties of the four herbicides in various aqueous micellar media, and we optimized the analytical conditions, including the SDS and CTAC concentrations of the micellar solutions, as well as the $\mathrm{pH}, \mathrm{UV}$ irradiation time and analytical excitation and emission wavelength values, for each individually-studied herbicide [16]. In order to analyze the synthetic binary mixtures of herbicides, we decided to choose compromised optimum analytical conditions, in order to keep the measured MEPIF signal of the mixtures analytically-suitable for the quantitative studies. Table 1 summarizes these new optimum analytical conditions for the two binary mixtures under study (chlorsulfuron/metsulfuron methyl and sulfometuron methyl/3rimsulfuron). The optimized, mean analytical MEPIF excitation $\left(\lambda_{e x}^{m}\right)$ wavelength used for each binary mixture was taken as the arithmetic average of the $\lambda_{\text {ex }}$ values of both components, and an identical optimum UV irradiation time ( $t_{\text {irr }}^{\text {opt }}$ ) value was selected for both components in each mixture.

When recorded under optimum conditions, the individual MEPIF emission spectra of the herbicides under study severely overlapped, the overlapping effect being more prominent in the case of chlorsulfuron and metsulfuron methyl than in that for sulfometuron and 3-rimsulfuron (Fig. 1 and 2). These spectral features mean that the conventional calibration procedures could not be satisfactorily applied for the quantitative resolution of the corresponding mixtures. Also, the determination of both components can be complicated by the occurrence of intermolecular interactions taking place between the different sulfonylurea herbicides within the mixtures. This particular phenomenon can be observed in both figures, in which the experimental MEPIF emission spectra obtained from a binary mixture was compared to the theoretically-expected spectra for the same mixture, i.e., the MEPIF spectra calculated by numerically averaging the MEPIF signals from each independently-taken pure substance. Indeed, as it can be seen in Figures 1 and 2, it appears that the mixture experimental and calculated MEPIF spectra differed in both intensity and shape, therefore suggesting that, not only is the proportionality relationship between the MEPIF signal intensity and herbicide concentra- tion not simple, but that it also depends on the occurrence of intermolecular interactions.

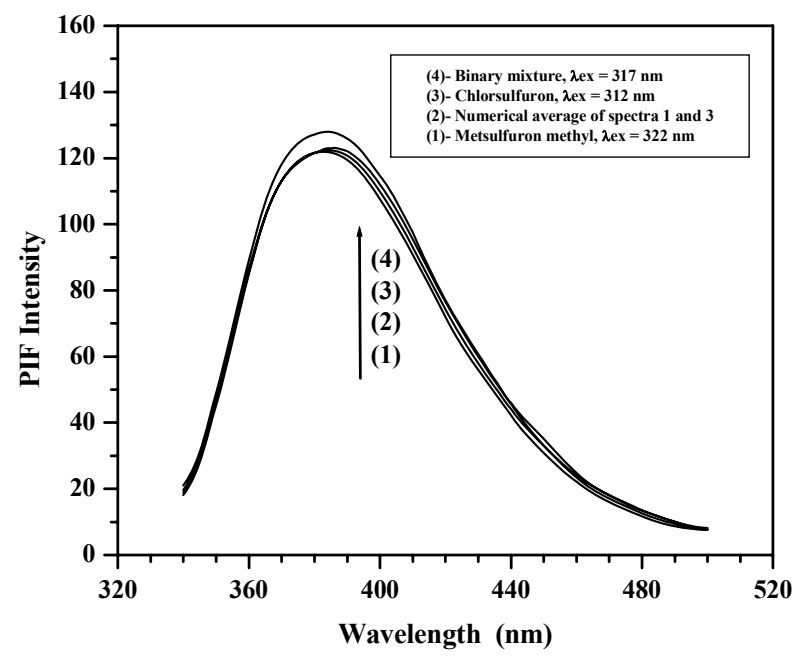

Fig. 1. Experimental MEPIF emission spectra of: (1) metsulfuron methyl $(61.5 \mathrm{ng} / \mathrm{mL})-\lambda_{\mathrm{ex}}=322 \mathrm{~nm}$; (3) chlorsulfuron ( $360.0 \mathrm{ng} / \mathrm{mL})-\lambda_{\mathrm{ex}}=312 \mathrm{~nm}$; (4) a mixture of both herbicides in the same concentration ratio $-\lambda_{\mathrm{ex}}=317 \mathrm{~nm}$. The curve (2) represents the numerically-averaged MEPIF emission spectra of the pure substances (spectra 1 and 3)

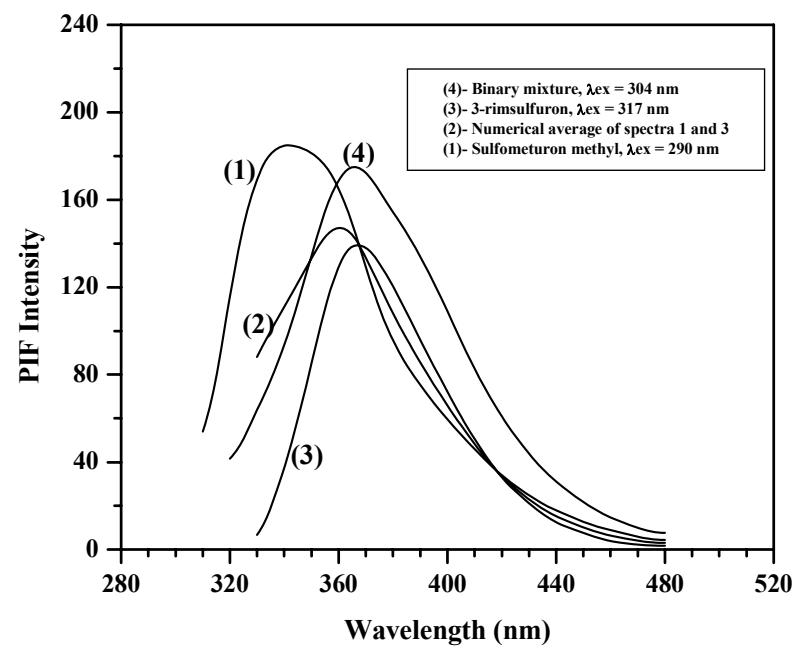

Fig. 2. Experimental MEPIF emission spectra of: (1) sulfometuron methyl $(728.0 \mathrm{ng} / \mathrm{mL})-\lambda_{\mathrm{ex}}=290 \mathrm{~nm}$; (3) 3-rimsulfuron ( $136.1 \mathrm{ng} / \mathrm{mL})-\lambda_{\mathrm{ex}}=317 \mathrm{~nm}$; (4) a mixture of both pesticides in the same concentration ratio $-\lambda_{\mathrm{ex}}=304 \mathrm{~nm}$. The curve (2) represents the numerically-averaged MEPIF emission spectra of the pure substances (spectra 1 and 3)

\section{Experimental design of the calibration matrices for the PLS-1-MEPIF method}

The PLS-1 technique is a typical fullspectrum method where the analytical signal data are fitted to many other data points, thus improv- 
ing the analytical precision. For the experimental design of the calibration matrices, we selected the MEPIF emission spectral region between 340 and $500 \mathrm{~nm}$ for the chlorsulfuron/metsulfuron methyl mixtures, and 320 and $480 \mathrm{~nm}$ for the sulfometuron methyl/3-rimsulfuron mixtures, with 161 points/spectrum. We used a training set of ten samples of various concentrations for each of the type of binary mixtures under study, as indicated in Table 2. The concentration ranges investigated for each mixture component were, respectively, 288-720 ng mL $\mathrm{mL}^{-1}$ / 23-70 $\mathrm{ng} \mathrm{mL}^{-1}$ for the chlorsulfuron/metsulfuron methyl mixtures and 145-730 $\mathrm{ng} \mathrm{mL} \mathrm{L}^{-1} / 17-130 \mathrm{ng} \mathrm{mL} \mathrm{L}^{-1}$ for the sulfometuron methyl/3-rimsulfuron mixtures. All MEPIF emission spectra were recorded using mean excitation wavelength constant values of $\lambda_{\mathrm{ex}}^{\mathrm{m}}=317 \mathrm{~nm}$ and $\lambda_{\mathrm{ex}}^{\mathrm{m}}=304 \mathrm{~nm}$, respectively, for the first and second type of mixtures (Table 1).

Table 1

MEPIF optimum analytical conditions used for the determination of sulfonylurea herbicides in binary mixtures

\begin{tabular}{|c|c|c|c|c|c|}
\hline Binary mixture & $\begin{array}{l}\text { Medium } \\
(\mathrm{mol} / \mathrm{L})\end{array}$ & $\begin{array}{c}\lambda_{\mathrm{ex}} / \lambda_{\mathrm{em}}^{\mathrm{a})} \\
(\mathrm{nm})\end{array}$ & $\mathrm{pH}$ & $\begin{array}{l}\left.\lambda_{e x}^{\mathrm{m}} \mathrm{c}\right) \\
(\mathrm{nm})\end{array}$ & $\begin{array}{c}t_{\text {irr }}^{\text {opt d) }} \\
(\mathrm{s})\end{array}$ \\
\hline Chlorsulfuron & $\begin{array}{l}{[\mathrm{SDS}]} \\
6 \cdot 10^{-2}\end{array}$ & $312 / 398$ & $11.8^{\mathrm{b})}$ & 317 & 150 \\
\hline Metsulfuron-Me & $\begin{array}{l}{[\mathrm{SDS}]} \\
6 \cdot 10^{-2}\end{array}$ & $322 / 378$ & $11.8^{\mathrm{b})}$ & & \\
\hline Sulfometuron-Me & $\begin{array}{c}{[\mathrm{CTAC}]} \\
2 \cdot 10^{-3}\end{array}$ & $290 / 341$ & 8 & 304 & 150 \\
\hline 3-Rimsulfuron & $\begin{array}{c}{[\mathrm{CTAC}]} \\
2 \cdot 10^{-3}\end{array}$ & $317 / 365$ & 8 & & \\
\hline
\end{tabular}

\footnotetext{
a). Analytical excitation $\left(\lambda_{\text {ex }}\right)$ and emission $\left(\lambda_{\text {em }}\right)$ maximum wavelength values of the MEPIF spectra.

${ }^{\text {b) }} \mathrm{pH}$ value corresponding to $[\mathrm{NaOH}]=5 \cdot 10^{-3} \mathrm{~mol} / \mathrm{L}$.

c) $\lambda \lambda_{\mathrm{ex}}^{\mathrm{m}}=$ analytical excitation wavelength value used for the binary mixtures, corresponding to the arithmetic average of the $\lambda_{\mathrm{ex}}$ values of the two components of the mixtures.

${ }^{\mathrm{d})}$ Compromised optimum irradiation time ( $\left.t_{\text {irr }}^{\text {opt }}\right)$ value used for the mixtures.
}

Table 2

\section{Results of the calibration matrices obtained for the PLS-1-MEPIF determination of ten samples of sulfonylurea herbicide binary mixtures in various concentration ratios}

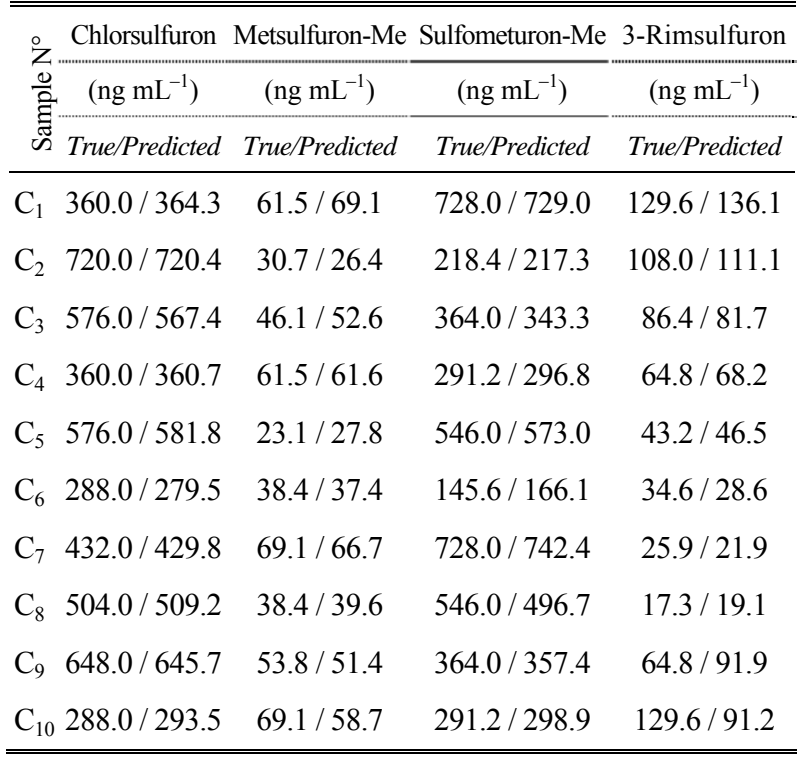

\section{Selection of the optimum number of factors and statistical parameters}

In order to select the optimum number of factors in the PLS-1 algorithm used to model the system without overfitting the concentration data, we applied a cross-validation procedure, leaving out one sample at a time. The herbicide concentration of each binary mixture was then predicted and compared with the known, experimental concentration of the corresponding mixture.

The prediction errors sum of squares (PRESS) is a measure of how well the training set can predict the concentration for each number of factors. We used the convenient F-ratio probability value to estimate the significance of a PRESS value greater than the minimum. It can be considered that, as the difference between the minimum PRESS value and other PRESS values becomes smaller, the probability that each additional factor is really significant decreases. Empirically, it is recommended to choose a number of factors for the PRESS value corresponding to an $F$ ratio probability below 0.75 , since using the number of factors that gives a minimum PRESS value generally leads to some overfitting [3a, 13]. The plots of the PRESS values $v s$ the number of factors, generated from prediction of chlorsulfuron, metsulfuron 
methyl, sulfometuron methyl and 3-rimsulfuron by the PLS-1 method, are given in Figs. 3 and 4. Under these conditions, the application of the software program indicated that six and three were the optimum number of factors, respectively, in the case of chlorsulfuron and metsulfuron methyl prediction, whereas five and three were used as optima, respectively, for sulfometuron methyl and 3rimsulfuron prediction (Table 3 and Fig. 3 and 4).

Table 3

\section{Statistical parameters of the calibration matrices used for the PLS-1-MEPIF simultaneous determination of the binary mixtures of sulfonylurea herbicides under study}

\begin{tabular}{lcccc}
\hline \hline Binary mixtures & $\begin{array}{c}\text { Number } \\
\text { of factors }\end{array}$ & RMSD $^{\text {a) }}$ & $r^{\mathrm{b})}$ & $\begin{array}{c}\mathrm{REP}^{\mathrm{c})} \\
(\%)\end{array}$ \\
\hline Chlorsulfuron & 6 & 5.2 & 0.999 & 1.1 \\
Metsulfuron-Me & 3 & 2.1 & 0.991 & 4.3 \\
\hline Sulfometuron-Me & 5 & 14.8 & 0.997 & 3.5 \\
3-Rimsulfuron & 3 & 5.8 & 0.990 & 8.2 \\
\hline \hline \multicolumn{4}{c}{${ }^{\text {a) }}$ RMSD = root mean square difference. } \\
$\begin{array}{l}\text { b) } r=\text { correlation coefficient. } \\
\text { c) REP = relative error of prediction. }\end{array}$
\end{tabular}

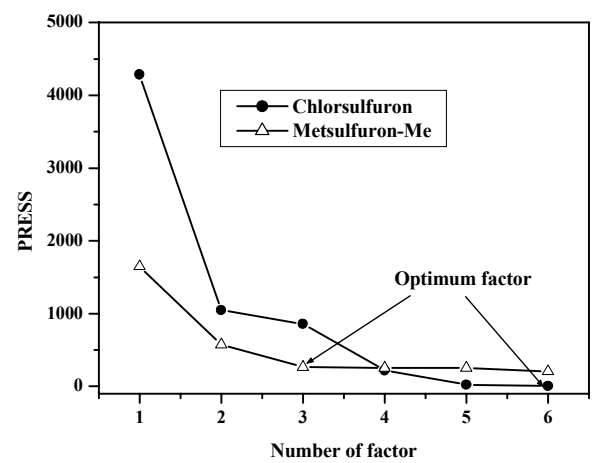

Fig. 3. PRESS plot and optimum number of factors generated from prediction of $(\bullet)$ chlorsulfuron and $(\Delta)$ metsulfuron methyl by the PLS-1-MEPIF method

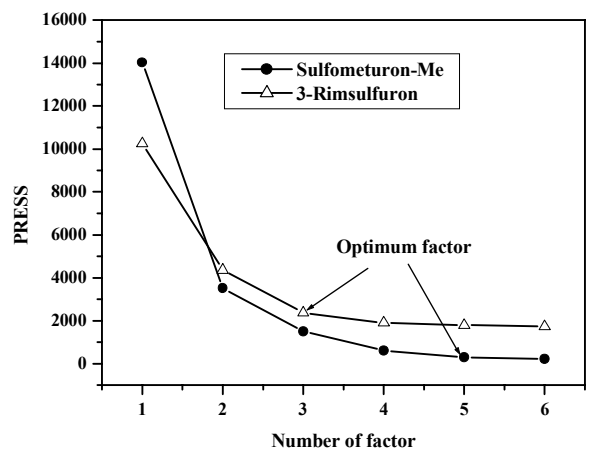

Fig. 4. PRESS plot and optimum number of factors generated from prediction of $(\bullet)$ sulfometuron methyl and $(\Delta)$ 3-rimsulfuron by the PLS-1-MEPIF method
The predicted concentrations of the various binary mixture samples under study are shown in Table 2, and are compared with the true concentration values. The agreement between the predicted and true concentration values is rather satisfactory in most cases. In these predictions, both the mean error and the relative standard deviation obtained can be regarded as acceptable. Indeed, when the concentrations predicted by the PLS- 1 model for the training set were plotted $v s$. the true concentrations of the four herbicides, straight lines with correlation coefficient $(r)$ values larger than 0.99 were obtained. We present in Table 3 the values obtained for the various statistical parameters, generally used in the PLS-1 method [5, 6, 13], including the root mean square difference (RMSD), the relative error of prediction (REP, in \%) and the correlation coefficient $(r)$. The RMSD values represent an estimation of the absolute error of prediction for each component. For both types of binary mixtures investigated, the found RMSD values ranged from 2.1 to 14.8 , depending on the herbicide, which can be considered as satisfactory. The $r$ values were comprised between 0.990 and 0.999 , and the REP values were going from 1.1 to $8.2 \%$, according to the herbicide, which is acceptable.

\section{Analysis of spiked tap water samples}

Tap water samples spiked with binary mixtures of the herbicides were investigated. The optimized calibration matrices were applied to the simultaneous determination of mixtures of chlorsulfuron/metsulfuron methyl and sulfometuron methyl/3-rimsulfuron in samples of spiked Paris drinking water. Eight series of samples of the binary mixtures were prepared and processed according to the proposed PLS-1-MEPIF method. The obtained results show that the recovery values of the chlorsulfuron/metsulfuron methyl mixture (Table 4) were in the range of $74-118 \%$ for chlorsulfuron and $72-86 \%$ for metsulfuron methyl. In the case of the sulfometuron methyl/3-rimsulfuron mixture (Table 5), the recovery values were within the 78-99 \% range in the case of sulfometuron methyl and the 70-106\% range for 3-rimsulfuron. In most instances, these recovery values are satisfactory. However, in the case of metsulfuron methyl, the recovery values are significantly lower than expected, relative to that of the other components of the mixtures. This is probably due to the fact that a compromised optimum irradiation time 
$\left(t_{\mathrm{irr}}^{\mathrm{opt}}\right)$ value of $150 \mathrm{~s}$ was chosen for this mixture, while the optimum UV irradiation time of the herbicide metsulfuron methyl, taken alone, was only $60 \mathrm{~s}$ [16]. Under these conditions, the obtained metsulfuron methyl fluorescent photoproduct might be photolysed into a weakly fluorescent byproduct because of the longer irradiation time which had to be selected for the PIF study of the corresponding mixture.

Table 4

Recovery values of chlorsulfuron/metsulfuron methyl mixtures, obtained by the PLS-1-MEPIF method

\begin{tabular}{|c|c|c|c|c|c|c|}
\hline \multicolumn{3}{|c|}{$\begin{array}{l}\text { Chlorsulfuron } \\
\left(\mathrm{ng} \mathrm{mL}^{-1}\right)\end{array}$} & \multicolumn{4}{|c|}{$\begin{array}{l}\text { Metsulfuron methyl } \\
\qquad\left(\text { ng } \mathrm{mL}^{-1}\right)\end{array}$} \\
\hline Added & Found & $\begin{array}{c}\text { Recovery } \\
\text { (\%) }\end{array}$ & $\begin{array}{l}\text { Concen- } \\
\text { tration } \\
\text { ratio }^{\text {a) }}\end{array}$ & Added & Found & $\begin{array}{l}\text { Recovery } \\
(\%)\end{array}$ \\
\hline 576 & 528 & 91.7 & $9.4: 1$ & 61.5 & 50.5 & 82.1 \\
\hline 288 & 339 & 117.7 & 4.2:1 & 69.1 & 53.2 & 77.0 \\
\hline 648 & 564 & 87.0 & 21:1 & 30.7 & 26.5 & 86.3 \\
\hline 504 & 375 & 74.4 & 9.4:1 & 53.8 & 40.9 & 76.0 \\
\hline 432 & 380 & 88.0 & $9.4: 1$ & 46.1 & 34.5 & 74.9 \\
\hline 576 & 457 & 79.4 & $9.4: 1$ & 61.5 & 44.2 & 71.9 \\
\hline 720 & 552 & 76.7 & $24: 1$ & 23.1 & 16.9 & 73.2 \\
\hline
\end{tabular}

Table 5

\section{Recovery values of sulfometuron methyl/3- rimsulfuron mixtures, obtained by the PLS-1-MEPIF method.}

\begin{tabular}{ccccccc}
\hline \hline $\begin{array}{c}\text { Sulfometuronmethyl } \\
\left.(\mathrm{ng} \mathrm{mL})^{-1}\right)\end{array}$ & \multicolumn{5}{c}{$\begin{array}{c}\text { 3-Rimsulfuron } \\
\left(\mathrm{ng} \mathrm{mL}^{-1}\right)\end{array}$} \\
Added & Found & $\begin{array}{c}\text { Recovery } \\
(\%)\end{array}$ & $\begin{array}{c}\text { Concen } \\
\text { tration ratio }{ }^{\text {a) }}\end{array}$ & Added Found & $\begin{array}{c}\text { Recovery } \\
(\%)\end{array}$ \\
\hline 364 & 358 & 98.4 & $8.4: 1$ & 43.2 & 45.7 & 105.8 \\
546 & 452 & 82.8 & $8.4: 1$ & 64.8 & 57.5 & 88.8 \\
728 & 566 & 77.8 & $8.4: 1$ & 86.4 & 69.0 & 79.9 \\
364 & 311 & 85.5 & $2.8: 1$ & 129.6 & 91.0 & 70.2 \\
728 & 593 & 81.5 & $21: 1$ & 34.6 & 27.0 & 78.0 \\
546 & 514 & 94.2 & $21: 1$ & 25.9 & 26.3 & 101.6 \\
218.4 & 214.3 & 98.2 & $12.6: 1$ & 17.3 & 14.9 & 86.2 \\
\hline \hline
\end{tabular}

\footnotetext{
a) Concentrations expressed in $\mathrm{ng} \mathrm{mL}^{-1}$
}

\section{Advantages of the PLS-1-MEPIF method for determination of sulfonylurea herbicides}

The results obtained by using the PLS-1 approach for the MEPIF determination of sulfonylurea herbicides in binary mixtures demonstrate several important analytical advantages relative to the other methods described in the literature $[4,7$, $18]$.

Indeed, the PLS-1-MEPIF method is a fullspectrum technique, which improves the precision of the quantitative analysis. Moreover, within the calibration or training set, the levels of any interference do not need to be known. In these conditions, the analysis time is reduced, since it is not requested to perform complicated sample pretreatment and interference study $[4,7]$.

Also, when compared to the ${ }^{1} \mathrm{D}$-PIF technique, the PLS-1-MEPIF method appears to be more selective for the resolution of herbicide mixtures. Indeed, several binary mixtures of sulfonlurea herbicides, such as the chlorsulfuron-metsulfuron methyl mixture could not be resolved by the ${ }^{1}$ D-PIF method, because of the stronglyoverlapping PIF emission peaks [18]. On the contrary, in the present study this latter mixture was satisfactorily resolved by the PLS-1-MEPIF method. Therefore, the PLS-1-MEPIF method can be considered as complementary to the ${ }^{1} \mathrm{D}-\mathrm{PIF}$ technique, and, in some instances, to be even superior for the quantitative analysis of binary mixtures of sulfonylurea herbicides.

\section{CONCLUSION}

In this study, we have developed a simple, rapid, precise and novel PLS-1-MEPIF method for the successful, simultaneous determination of individual herbicide concentrations in binary mixtures of sulfonylurea herbicides (chlorsulfuron/metsulfuron methyl and sulfometuron methyl/3rimsulfuron) at the trace level in tap water. The method can quantitatively resolve the severely overlapped MEPIF spectra of sulfonylurea herbicides, recorded in the presence of surfactants SDS or CTAC, with the PLS-1 algorithm. Therefore, the PLS-1-MEPF method is particularly useful for the determination of mixtures of photoreactive analytes such as sulfonylurea herbicides, which are characterized by very similar PIF spectra. This method constitutes a great improvement in terms 
of selectivity, in comparison with the other previously-reported PIF methods for the quantification of sulfonylurea herbicides [16-18]. Also, the method can be used for the rapid determination of traces of sulfonylurea herbicide residues in natural water samples, by applying a simple preconcentration step and without the need of a complex separation step.

Acknowledgements. We thank DuPont de Nemours and Co., Inc. for the kind gift of standard herbicides. A. Coly warmly thanks the University Paris Diderot (Paris-7) for financial support during his stay in France.

\section{REFERENCES}

[1] W. Lindberg, J.-A Persson, S. Wold, Partial least-squares method for spectrofluorimetric analysis of mixtures of humic acid and lignin sulfonate, Anal. Chem. 55, 643648 (1983).

[2] K. R. Beebe, B. R. Kowalski, An introduction to multivariate calibration and analysis, Anal. Chem. 59, 1007A1017A (1987).

[3] a) D. M. Haaland, E. V. Thomas, Partial least-squares methods for spectral analyses. 1. Relation to other quantitative calibration methods and the extraction of qualitative information, Anal. Chem. 60, 1193-1202 (1988).

b) E. V. Thomas, D. M. Haaland, Comparison of multivariate calibration methods for quantitative spectral analysis, Anal. Chem. 62, 1091-1099 (1990).

[4] A. Espinosa-Mansilla, A. Muñoz de la Peña, F. Salinas, A. Zamora, Simultaneous determination of pesticides by multivariate spectral analysis and derivative spectrophotometry, Anal. Chim. Acta 258, 47-53 (1992).

[5] M. Sanchez-Peña, A. Muñoz de la Peña, F. Salinas, M.C. Mahedero, J.-J. Aaron, Determination of binary mixtures of sulfonamides by photochemically induced fluorescence using partial least squares multivariate calibration, Analyst 119, 1177-1181 (1994).

[6] M. Martinez-Galera, J. L. Martinez-Vidal, A. GarridoFrenich, P. Parrilla-Vasquez, Multicomponent determination of atrazine, diuron and chlorpyrifos in groundwaters and soils by spectrophotometry using multivariate calibration Analyst 119, 1189-1194 (1994).
[7] R. Corbella-Teña, M. A. Rodriguez-Delgado, M. J. Sanchez, F. Garcia-Montelongo, Comparative study of the ratio spectra derivative and partial least squares methods applied to the simultaneous determination of atrazine and ametryn in ground waters, Analyst 121, 459-463 (1996).

[8] I. Eide, H. G. Johnsen, Mixture design and multivariate analysis in mixture research, Environ. Health Perspect. Supl. 106, 1373-1376 (1998).

[9] K. Kargosha, S. H. Ahmadi, A. Ghassempour and M. R. Arshadi, Simultaneous determination of pesticide naptalam and its metabolites in natural water by Fourier transform infrared spectrometry, Analyst 124, 367 (1999).

[10] A. Garrido-Frenich, J. L. Martinez-Vidal, M. MartinezGalera, Use of the cross-section technique linked with multivariate calibration methods to resolve complex pesticides mixtures Anal. Chem. 71, 4844-4850 (1999).

[11] P. Parrilla-Vasquez, M. Martinez-Galera, A. GarridoFrenich, J.L. Martinez-Vidal, Comparison of calibration methods with and without feature selection for the analysis of HPLC data, Anal. Sci. 16, 49-55 (2000).

[12] A. D. Vidal, P. O. Barales, A. M. Diaz, Environmental water samples analysis of pesticides by means of chemometrics combined with fluorimetric multioptosensing, J. Fluorescence 17, 271-277 (2007).

[13] E.M. Almansa-Lopez, A.M. Garcia-Campana, J.J. Aaron, L. Cuadros-Rodriguez, Micellar-enhanced photochemically induced fluorescence determination of chlorophenoxyacid herbicide mixtures using multivariate calibration, Luminescence 17, 217-219 (2002).

[14] H. M. Brown, Mode of action, crop selectivity, and soil relations of the sulfonylurea herbicides, Pestic. Sci. 29, 263-281 (1990).

[15] J. V. Hay, Chemistry of sulfonylurea herbicides, Pestic. Sci. 29, 247-261 (1990).

[16] A. Coly, J.-J. Aaron, Photochemically-induced fluorescence determination of sulfonylurea herbicides using micellar media, Talanta 49, 107-117 (1999).

[17] A. Coly, J.-J. Aaron, Sensitive and rapid flow injection analysis of sulfonylurea herbicides in waters with micellar-enhanced photochemically induced fluorescence detection, Anal. Chim. Acta 392, 255-264 (1999).

[18] A. Coly, J.-J. Aaron, Simultaneous determination of binary mixtures of sulfonylurea herbicides in water by firstderivative photochemically induced spectrofluorimetry, $J$. AOAC Int. 84, 1745-1750 (2001). 